\title{
Risk factors for non-adherent retained placenta after vaginal delivery: a systematic review
}

\author{
Alessandro Favilli ${ }^{1}$, Valentina Tosto ${ }^{2}$, Margherita Ceccobellii ${ }^{2}$ Fabio Parazzini ${ }^{3}$, Massimo Franchi ${ }^{1}$, Vittorio Bini ${ }^{4}$ and \\ Sandro Gerli ${ }^{2^{*}}$ (D)
}

\begin{abstract}
Background: Retained placenta represents a cause of maternal morbidity and mortality affecting $0.5-3 \%$ of all vaginal deliveries. The unpredictability of this condition makes difficult to develop predictive and preventive strategies to apply in clinical practice. This analysis collected and analyzed all known risk factors related to this obstetric complication.

Methods: A systematic literature review for all original research articles published between 1990 and 2020 was performed. Observational studies about retained placenta risk factors published in English language were considered eligible. Conference abstracts, untraceable articles and studies focused on morbidly adherent placenta were excluded. The included articles were screened to identify study design, number of enrolled patients and retained placenta risk factors investigated. All stages of the revision followed the Preferred Reporting Items for Systematic Reviews and Meta-Analyses (PRISMA) Statement.
\end{abstract}

Results: Thirty-five studies met the inclusion criteria. The reported retained placenta prevalence ranged from 0.5 to 4.8\%. Maternal age, previous cesarean sections, previous dilation and curettage, previous retained placenta, labor induction, resulted as the most recurrent, independent risk factors for retained placenta. Previous estro-progestins therapy, morphological placental features (weight, shape, insertion of umbilical cord, implantation site), endometriosis, Assisted Reproductive Technologies, Apgar score are fascinating new proposal risk factors.

Conclusions: Old and new data are not enough robust to draw firm conclusions. Prospective and well-designed studies, based on a well agreed internationally retained placenta definition, are needed in order to clarify this potential dramatic and life-threatening condition.

Keywords: Retained placenta, Morbidly adherent placenta, Vaginal delivery, Prolonged third stage of labor, Risk factors, Post-partum hemorrhage

\footnotetext{
*Correspondence: sandro.gerli@unipg.it

${ }^{2}$ Department of Medicine and Surgery, Obstetrics and Gynecology, Centre of Perinatal and Reproductive Medicine, Santa Maria della Misericordia Hospital, University of Perugia, 06156 Perugia, Italy

Full list of author information is available at the end of the article
}

(C) The Author(s). 2021 Open Access This article is licensed under a Creative Commons Attribution 4.0 International License, which permits use, sharing, adaptation, distribution and reproduction in any medium or format, as long as you give appropriate credit to the original author(s) and the source, provide a link to the Creative Commons licence, and indicate if changes were made. The images or other third party material in this article are included in the article's Creative Commons licence, unless indicated otherwise in a credit line to the material. If material is not included in the article's Creative Commons licence and your intended use is not permitted by statutory regulation or exceeds the permitted use, you will need to obtain permission directly from the copyright holder. To view a copy of this licence, visit http://creativecommons.org/licenses/by/4.0/ The Creative Commons Public Domain Dedication waiver (http://creativecommons.org/publicdomain/zero/1.0/) applies to the data made available in this article, unless otherwise stated in a credit line to the data. 


\section{Background}

Retained placenta (RP) affects $0.5-3 \%$ of all vaginal deliveries and is considered one of the major causes of primary and secondary postpartum hemorrhage (PPH), increasing maternal morbidity and mortality risk [1-5]. Incidence of $\mathrm{RP}$ varies greatly around the world depending on the population studied $[5,6]$. Not only RP per se, but also its removal is associated with several complications such as infections, trauma of the urogenital tract, prolonged hospitalization and anesthesiological risks $[7,8]$.

The pathophysiology of this condition is not perfectly known and it is probably complex. Three major mechanisms for RP have been suggested: invasive placentation, placental hypoperfusion and inadequate myometrial contractility. The first one usually results from previous uterine trauma; the second mechanism could be related to incomplete spiral artery remodeling and shallow placentation. Lastly, localized retroplacental contractility failure was suggested to play a role in retention $[2,5,9,10]$.

At present, only a few number of risk factors for RP have been recognized with certainty. A previous retained placenta, older maternal age and prolonged use of oxytocin have been demonstrated to be correlated to RP. But instead, conflicting results have been reported about the role of parity, smoking, gestational diabetes as well as Assisted Reproductive Technologies (ART) [2, 3, 6, 7, 9]. This makes difficult to develop useful, concrete, predictive and preventive strategies.

The aim of this paper was to systematically search the relevant databased and give a description of all risk factors associated with retained placenta after vaginal delivery.

\section{Methods}

We performed a systematic literature search for all original research articles using the following database: PubMed/MEDLINE, Embase, Scopus and Google Scholar. We used both free text and a MeSH search for keywords including "retained placenta", "morbidly adherent placenta", "vaginal delivery", "prolonged third stage of labor", "risk factors", "post-partum hemorrhage", published between 1990 and 2020. Observational studies published in English language (case-controls, cohorts, cross sectionals studies) were considered eligible if dealing with RP risk factors. Studies including placenta accreta were excluded, as it is a well-known RP cause, but our aim was to investigate risk factors behind a nonpathologically adherent placenta. As well, studies focused on trapped placenta were excluded. Trapped placenta is the condition in which the placenta is trapped behind a closing cervix; it is rare and more relevant in very preterm labor, and little is known about it [9]. Conference abstracts were not included in the analysis. If any data was missing, the investigator of the study was contacted by e-mail for additional information.

A PICOS (Patient, Intervention, Comparator, Outcome, Study) design structure was used to develop the study question and the inclusion/exclusion criteria. The question was: "What are the risk factors for retained placenta?"

All the design, analysis, interpretation of data, drafting and revisions followed the Preferred Reporting Items for Systematic Reviews and Meta-Analyses (PRISMA) Statement [11], available through the Enhancing the QUAlity and Transparency Of Health Research (EQUATOR) network. The review was registered in PROSPERO database (registration number: CRD42018102190).

Titles and/or abstracts of retrieved articles were screened to identify studies that potentially met the inclusion criteria. Duplicates were removed and the remaining references were examined independently by two authors (M. C. and V. T.). The full texts of these studies were retrieved and independently assessed for eligibility by other authors (A. F., F. P., M.F., V.B. and S. G.). Any disagreement between them over the eligibility of particular studies was resolved through collective discussion. A standardized form was used to extract data from the included studies for assessment of study quality and evidence synthesis. We selected information about study design, number of patients enrolled and risk factors for RP investigated.

\section{Results}

The flow chart for search and identification of studies in the review is reported in Additional file 1 (PRISMA flow diagram). Using the reported search modality, 240 references were found. Duplicate references were 76 and therefore removed. A total of 164 studies were selected, but 4 were excluded due to the fact that insufficient data were available or were not provided by the authors. One hundred and fifty-eight papers were screened; 123 were excluded because considered outside the purpose. Lastly, 37 studies met our inclusion criteria and were eligible for the review. The design of the selected studies was as follows: 32 retrospective analysis, 4 prospective analysis and 1 study was both retrospective and prospective. The analyzed studies are summarized in Table 1, where different definitions of retained placenta are summarized.

\section{Prevalence}

As reported in Table 1, the RP prevalence ranged from 0.5 to $4.8 \%$. Nevertheless, Shinar et al. described a RP prevalence of $9 \%$. This gap could be explained by the inclusion of placental manual extractions due to vaginal bleeding or incomplete placental separation, which have been performed before the one-hour waiting, expected 
Table 1 Relevant data of retrieved studies

\begin{tabular}{|c|c|c|c|c|c|c|}
\hline $\begin{array}{l}\text { Authors, year, } \\
\text { Country }\end{array}$ & Study Design & $\begin{array}{l}\text { Study } \\
\text { period } \\
\text { (years) }\end{array}$ & Overall deliveries (n) & $\begin{array}{l}\text { RP diagnosis } \\
\text { (min) and } \\
\text { definition }\end{array}$ & Prevalence of RP & Management \\
\hline $\begin{array}{l}\text { Meyer, } 2020 \\
\text { Israel, [12] }\end{array}$ & Retrospective & 8 & 16,867 & $60, D$ & $\begin{array}{l}6.5 \% \text { (including complete } \\
\text { and partial retained placenta) }\end{array}$ & Active \\
\hline $\begin{array}{l}\text { Granfors, } 2020 \\
\text { Sweden, [13] }\end{array}$ & Retrospective & 6 & 49,598 & $N S, E$ & $2.0 \%$ & NS \\
\hline $\begin{array}{l}\text { Rottenstreich, } 2019 \\
\text { Israel [14] }\end{array}$ & Retrospective & 13 & 170,009 & $40, C$ & $2.70 \%$ & Active \\
\hline $\begin{array}{l}\text { Ruiter, } 2019 \\
\text { Netherlands [15] }\end{array}$ & Retrospective & 11 & 359,737 & $N S, E$ & $\begin{array}{l}2.7 \% \text {, (first pregnancy), } 17 \% \\
\text { (recurrence in second pregnancy) }\end{array}$ & NS \\
\hline $\begin{array}{l}\text { Favilli, } 2018 \\
\text { Italy [16] }\end{array}$ & Retrospective & 10 & 22,749 & $30, B$ & $0.6 \%$ & Active \\
\hline $\begin{array}{l}\text { Rotem, } 2018 \\
\text { Israel [17] }\end{array}$ & Retrospective & 25 & 263,053 & $30, B$ & $\begin{array}{l}0.7 \% \text { (Hypertenstiyve disorders) } \\
0.6 \% \text { (No hypertensyve disorders) }\end{array}$ & Active \\
\hline $\begin{array}{l}\text { Vannuccini, } 2018 \\
\text { Italy [18] }\end{array}$ & Retrospective & 5 & $\begin{array}{l}1168 \text { (Spontaneous } \\
\text { pregnancies) } \\
188 \text { (ART pregnancies) }\end{array}$ & $N S, E$ & $\begin{array}{l}6.30 \% \text { (ART pregnancies) } \\
2.8 \% \text { (spontaneous pregnancies) }\end{array}$ & NS \\
\hline $\begin{array}{l}\text { Endler, } 2017 \text { Sweden } \\
\text { [19] }\end{array}$ & Retrospective & 40 & 494,000 & $30, B$ & $\begin{array}{l}2.4 \% \text {, (index births) } 3.2 \% \text { (second } \\
\text { generation births) }\end{array}$ & $\begin{array}{l}\text { Observational } \\
+ \text { active }\end{array}$ \\
\hline $\begin{array}{l}\text { Greenbaum, } 2017 \\
\text { Israel [9] }\end{array}$ & Retrospective & 25 & 205,522 & $30, B$ & $4.8 \%$ & Observational \\
\hline $\begin{array}{l}\text { Anteby, } 2017 \\
\text { Israel [7] }\end{array}$ & Prospective & 2 & 19,359 & $60, D$ & $1.5 \%$ & Active \\
\hline $\begin{array}{l}\text { Alufi, } 2017 \\
\text { Israel [6] }\end{array}$ & Retrospective & 4 & 18,146 & $30, B$ & $0.5 \%$ & Observational \\
\hline $\begin{array}{l}\text { Berlac, } 2017 \\
\text { Denamark [20] }\end{array}$ & Retrospective & 14 & $\begin{array}{l}11,739 \\
\text { (women with } \\
\text { endometriosis disease) }\end{array}$ & NS, E & $2.20 \%$ & Observational \\
\hline $\begin{array}{l}\text { Aziz, } 2016 \\
\text { New Jersey [21] }\end{array}$ & Retrospective & 5 & 769 & NS, E & $\begin{array}{l}\text { 1.05\% (ART pregnancies) } \\
1 \% \text { (spontaneous pregnancies) }\end{array}$ & NS \\
\hline $\begin{array}{l}\text { Sarit, } 2016 \\
\text { Israel [22] }\end{array}$ & Retrospective & 0,5 & 4227 & $60, D$ & $1.9 \%$ & Active \\
\hline $\begin{array}{l}\text { Jackson, } 2015 \\
\text { California [23] }\end{array}$ & Retrospective & 11 & $\begin{array}{l}193 \text { (spontaneous } \\
\text { pregnancies } \\
185 \text { (ART pregnancies) }\end{array}$ & $N S, E$ & $\begin{array}{l}0 \% \text { (spontaneous pregnancies) } \\
2.7 \% \text { (ART pregnancies) }\end{array}$ & Observational \\
\hline $\begin{array}{l}\text { Shinar, } 2015 \\
\text { Israel [24] }\end{array}$ & Retrospective & 5 & 25,160 & $60, B$ & $9.00 \%$ & Active \\
\hline $\begin{array}{l}\text { John, } 2015 \\
\text { Nigeria [25] }\end{array}$ & Retrospective & 5 & 15,789 & $30, B$ & $0.59 \%$ & Observational \\
\hline $\begin{array}{l}\text { Coviello, } 2015 \text { USA } \\
\text { [3] }\end{array}$ & Retrospective & 6 & 228,562 & $30, B$ & $1.12 \%$ & Observational \\
\hline $\begin{array}{l}\text { Torricelli, } 2015 \text { Italy } \\
\text { [26] }\end{array}$ & Prospective & 3 & 2354 & $N S, E$ & NS & Observational \\
\hline $\begin{array}{l}\text { Ashwal, } 2014 \text { Israel } \\
\text { [27] }\end{array}$ & Retrospective & 5 & 33,925 & $30, B$ & $1.4 \%$ & Active \\
\hline $\begin{array}{l}\text { Endler, } 2014 \text { Sweden } \\
\text { [2] }\end{array}$ & Retrospective & 12 & 386,607 & $N S, E$ & $2.17 \%$ & Active \\
\hline $\begin{array}{l}\text { Magann, } 2013 \text { USA } \\
\text { [28] }\end{array}$ & Retrospective & 2 & 452 & $15, A$ & NS & Observational \\
\hline $\begin{array}{l}\text { Nikolajsen, } 2013 \\
\text { Denmark [29] }\end{array}$ & Retrospective & 9 & 10,334 & $30, B$ & $2.60 \%$ & Observational \\
\hline $\begin{array}{l}\text { Endler, } 2012 \text { Sweden } \\
\text { [30] }\end{array}$ & Retrospective & 3 & 16,209 & $30, B$ & $2.6 \%$ & Active \\
\hline $\begin{array}{l}\text { Farhi, } 2010 \\
\text { Israel [31] }\end{array}$ & Retrospective & 2 & 280 & $N S, E$ & NS & NS \\
\hline
\end{tabular}


Table 1 Relevant data of retrieved studies (Continued)

\begin{tabular}{|c|c|c|c|c|c|c|}
\hline $\begin{array}{l}\text { Authors, year, } \\
\text { Country }\end{array}$ & Study Design & $\begin{array}{l}\text { Study } \\
\text { period } \\
\text { (years) }\end{array}$ & Overall deliveries (n) & $\begin{array}{l}\text { RP diagnosis } \\
\text { (min) and } \\
\text { definition }\end{array}$ & Prevalence of RP & Management \\
\hline $\begin{array}{l}\text { Obajimi, } 2009 \\
\text { Nigeria [32] }\end{array}$ & Retrospective & 5 & 4980 & $30, B$ & $2.13 \%$ & Observational \\
\hline $\begin{array}{l}\text { Rizwan, 2009 } \\
\text { Pakistan [33] }\end{array}$ & $\begin{array}{l}\text { Retrospective }+ \\
\text { prospective }\end{array}$ & 3 & 8782 & $30, B$ & $1.02 \%$ & Active \\
\hline $\begin{array}{l}\text { Owolabi, } 2008 \\
\text { Nigeria [34] }\end{array}$ & Prospective & 7 & 6160 & $30, B$ & $1.9 \%$ & $\begin{array}{l}\text { Observational } \\
+ \text { active }\end{array}$ \\
\hline $\begin{array}{l}\text { Panpaprai, } 2007 \\
\text { Thailand [35] }\end{array}$ & Retrospective & 3 & $\begin{array}{l}234 \text { (78 cases, } 156 \\
\text { controls) }\end{array}$ & $30, B$ & NS & Observational \\
\hline $\begin{array}{l}\text { Chhabra, } 2002 \text { India } \\
\text { [8] }\end{array}$ & Retrospective & 15 & 29,784 & $N S, E$ & $0.23 \%$ & $\begin{array}{l}\text { Observational } \\
+ \text { active }\end{array}$ \\
\hline $\begin{array}{l}\text { Titz, } 2001 \\
\text { Australia [36] }\end{array}$ & Retrospective & 7 & 3734 & $60, D$ & $3.00 \%$ & Observational \\
\hline $\begin{array}{l}\text { Adelusi, } 1997 \text { Saudi } \\
\text { Arabia [37] }\end{array}$ & Retrospective & 5 & 22,045 & $N S, E$ & $0.06 \%$ & Observational \\
\hline $\begin{array}{l}\text { Soltan, } 1997 \\
\text { Saudi Arabia [38] }\end{array}$ & Retrospective & 6 & 26,315 & $60, D$ & $0.55 \%$ & Observational \\
\hline $\begin{array}{l}\text { Golan, } 1996 \\
\text { Israel [39] }\end{array}$ & Retrospective & NS & NS & NS & NS & NS \\
\hline $\begin{array}{l}\text { Dombrowski, } 1995 \\
\text { Michigan [40] }\end{array}$ & Prospective & 9 & 45,852 & $30, B$ & $2.00 \%$ & Active \\
\hline $\begin{array}{l}\text { Combs, } 1991 \\
\text { California [41] }\end{array}$ & Retrospective & 11 & 12,979 & $30, B$ & $3.3 \%$ & Observational \\
\hline $\begin{array}{l}\text { Romero,1990 } \\
\text { Connecticut [42] }\end{array}$ & Retrospective & 2 & 792 & $30, B$ & $3.40 \%$ & Observational \\
\hline \multicolumn{7}{|c|}{$\begin{array}{l}\text { NS Not Specified, RP Retained Placenta, ART Assisted Reproductive Technologies } \\
\text { RP Definition A: third stage of labor lasting > } 15 \mathrm{~min} \\
\text { RP Definition B: failure to deliver placenta after a } 30 \text {-min duration of an uncomplicated third stage } \\
\text { RP Definition C: failure to deliver placenta after a } 40 \text {-min or more duration of an uncomplicated third stage } \\
\text { RP Definition D: failure to deliver placenta after a } 60 \text {-min or more duration of an uncomplicated third stage } \\
\text { RP Definition E: placenta that reauires manual removal }\end{array}$} \\
\hline
\end{tabular}

by the Centre policy for the active management of the third stage of delivery.

\section{Demographic risk factors}

Parity, advanced maternal age, and ethnicity have been considered well-established RP risk factors. Coviello et al. observed a statistically significant association with multiparity (OR 4.56, 95\% CI 2.08-9.94) [3]. However, Ashwal observed that women with RP had lower parity (OR 0.79, 95\% CI 0.68-0.91) [27]; Endler that parity of two or more had a protective effect (OR 0.40, 95\% CI 0.24-0.70) [30] and Combs reported a higher risk for RP in nulliparous versus multiparous $(p<0.01)$ and in para $\geq 5$ vs para $<5(p<0.05)$ [41].

Frequency of RP was higher (37.7\%) in women aged 26-30 than in patients aged 34-40 (13.3\%) [33]. According to Coviello, RP was associated with older maternal age (27.5 years versus 26.6 years, $p<0.001)$ [3].

A higher rate of Jewish ethnicity (OR 1.12, 95\% CI 1.07-1.17) in the RP group was also found [9]. Otherwise, RP was related with non-Hispanic black or Asian women [3].
Compared with women with spontaneous placental expulsion, those with RP were with a higher Body Mass Index (BMI) [2,9]. Endler showed that 20.2\% of women with RP were overweight (OR 1.13, 95\% CI $1.07-1.21$ ) and $7.9 \%$ of women were obese (OR 1.28, 95\% CI 1.16-1.40) [2].

\section{Smoking}

Smoking during pregnancy was not significantly related to RP risk. Endler showed that $92.6 \%$ of women with RP did not smoke, while $7.6 \%$ were smokers [2]. Likewise, Greenbaum reported that women with RP were smokers in $0.5 \%$, while women with normal placental delivery had a smokers rate of $1.0 \%$ (OR $0.51,95 \%$ CI $0.39-0.67$ ) [9]. Even, Endler observed that smoking could have a protective effect on the prevalence of RP, speculating an effect of reduction of placental apoptotic process, similar to that of carbon monoxide in preventing preeclampsia [30].

\section{Previous uterine surgery}

A history of a previous uterine surgery, like cesarean section (CS), dilation and curettage (D\&C) and 
myomectomy, has been highlighted as independent RP risk factor (OR 8.82, 95\%CI 8.35-9.31 for previous CS; OR 12.80 , 95\%CI $10.57-15.50$ for previous D\&C; OR $1.97,95 \% \mathrm{CI} 1.05-3.71$ for history of other instrumental procedures) [9].

\section{Recurrence of RP}

Authors reported the history of RP as a risk factor for recurrence in subsequent pregnancies $[6,28,32,33]$. Nikolajsen et al. observed an increased risk among women with a history of RP after vaginal delivery with a prevalence ranging from 2.8 to $7.0 \%$ [29]. Endler found that there is an intergenerational RP recurrence, on the maternal and paternal side [19]. In this study, mothers born in a pregnancy complicated by RP had an increased risk of RP when giving birth themselves (OR 1.66, 95\% CI 1.52-1.82). Fathers born in a pregnancy complicated by RP had an increased risk of fathering a pregnancy complicated by RP (OR 1.23, 95\% CI 1.07-1.41).

Rottenstreich described the higher risk of RP recurrence in multiple consecutive deliveries. RP was diagnosed in $2.7 \%$ deliveries and $13.8 \%$ women had at least one RP recurrence in any of their subsequent deliveries: $85.7 \%$ had one additional episode, $11.3 \%$ two more events, $2.3 \%$ three more events [14]. Ruiter found that among women with a first pregnancy complicated by manual removal of placenta, $17 \%$ underwent the same procedure in the second pregnancy (OR 6.1, 95\% CI 5.6-6.7) [15].

\section{Uterine pathologies}

Women with history of endometriosis showed a higher RP risk (OR 3.1, 95\% CI 1.4-6.6) [20]. Moreover, authors described an association between morphological uterine anomalies and RP [5, 32]. At this regard, Golan found incomplete uterine septum at hysteroscopic examination in about $15 \%$ of women who underwent a manual removal of the placenta [39]. Uterine fibroids could be another RP risk factor: Rizwan showed that $7.7 \%$ patients with RP had uterine fibroids [33].

\section{Obstetrical risk factors}

Concerning labor management, oxytocin use and its exposure time during labor was related with RP. A retrospective study demonstrated that an increasing duration of oxytocin administration resulted as a RP risk factor; nevertheless, this was not confirmed by the logistic regression analysis [16]. This data is in contrast with previous results [30], asserting that it was not oxytocin per se to be involved in RP, but the consequences of its prolonged use that could exhaust the contractility myometrial force. Oxytocin use for 195-415 min led to a risk of RP two times higher than labor without it (OR 2.00, 95\% CI 1.20-3.34), whereas its use for more than $415 \mathrm{~min}$ related to a risk more than six times higher (OR 6.55, 95\% CI 3.42-12.54). Epidural analgesia, also, appeared to be significantly associated with placental disorders when added to oxytocin.

Instrumental vaginal delivery is another potential RP risk factor reported in several studies (OR 1.54, 95\% CI 1.45-1.63), (OR 1.89, 95\% CI 1.48-2.41), (OR 1.54, 95\% CI 1.47-1.62), $(p<0.0001)[2,16,19,27]$.

Pregnancies conceived with Assisted Reproductive Technologies have a significantly higher rate of placentation defects (OR 2.63, 95\% CI 1.31-5.26) [18]. Jackson showed a higher risk for RP in ART pregnancies than spontaneous conceptions $(2.7 \%$ vs $0 \%, p=0.02)$ and a higher risk for ART gestations conceived through donor oocytes versus autologous oocytes (3.3\% vs $1.6 \%$ ) [23]. However, Aziz showed an increased frequency of manual placental extraction only within women who underwent embryo transfer with no exposure to controlled ovarian hyperstimulation [21].

The Great Obstetrical Syndromes (GOS), a collective name for several pregnancy complications including gestational diabetes, hypertensive disorders, pre-eclampsia, intrauterine growth restriction (IUGR), preterm delivery and stillbirth, could be related to RP [2, 27]. RP was found strongly associated with preterm labor, particularly less than 27 weeks of gestation with a relative risk ranging from 6 to 13 [41, 42]. Obajimi observed that about $56.7 \%$ RP cases had a lower mean gestational age at delivery $(34.29+/-6.02$ weeks $)$ than RP cases at term (43.3\%) [32]. Dombrowski found the frequency of RP markedly increased among 20 to 26 weeks gestation (25.4\%, OR 20.8, 95\% CI 17.1-25.4) and among gestations < 37 weeks $(4.7 \%$, OR $3.8,95 \%$ CI $2.6-3.5)$ compared with term gestations (1.6\%) [40]. Romero et al. found that the incidence of RP was significantly higher in women with preterm vaginal delivery than in women with term vaginal delivery $(9.1 \%$ against $1.1 \%$, OR $=9.25$, $p<0.0001$ ) [42].

Concerning fetal characteristics, RP risk was increased by a lower birth weight, fetal growth restriction and stillbirth, which reflects the possible defective placentation on the fetal well-being $[2,3]$.

The strength of the association between diabetes (pregestational and gestational) and RP is difficult to evaluate [2]. Nevertheless, authors identified GDM as a risk factor for RP (OR 1.31, 95\% CI 1.21-1-43, $p<0.001$ ). Greenbaum considered GDM among the variables related to the placental hypoperfusion. This mechanism has been suggested as a common insult of both complications during pregnancy and abnormal detachment of the placenta during childbirth [9].

About hypertensive disorders, Rotem described a higher rate of third stage complications among hypertensive parturients $(4.7 \%$ versus $4.0 \%, p<0.001)$ and an 
independent correlation between RP and preeclampsia (OR 1.34, 95\% CI 1.10-1.63) [17].

\section{Placental histological data}

Endometritis and chorioamnionitis are associated with $\mathrm{RP}$ as possible causes of inadequate uterine contractility $(p<0.001)$ [9].

Several studies demonstrated a relation between RP and placental weight less than $500 \mathrm{~g}[20,35]$. The analysis of placental morphological characteristics after discharge allowed to confirm a statistically significant association between RP and lower placental weight ( $p=$ 0.0001) [16].

\section{"New proposed" RP risk factors}

A prospective study demonstrated that placental location, determined by ultrasonographic examination, influenced the onset and progress of labor and postpartum outcome: women with anterior placenta showed a prolonged third stage of labor $(p=0.01)$, a higher risk of manual placental removal $(p=0.003)$ and a higher rate of PPH in vaginal deliveries $(p=0.02)$ [26]. Otherwise, an association of RP and placental implantation site was demonstrated $(p=0.018)$; a higher rate of RP was shown when the placental site was anterior (anterior 47.9\%, fundic $22.7 \%$, posterior $20 \%$ and lateral 9.2\%) [16]. Meyer et al. found that lateral and fundal location of placenta were both associated with increased risk of third stage placental complications (partial or complete retained placenta (OR 2.05, 95\% CI 1.35-3.11; OR 1.65, 95\% CI 1.01-2.26, respectively) [12]. Finally, Granfors conducted an analysis, including women with a previous cesarean section, demonstrating that the risk for retained placenta was not increased with anterior compared with non-anterior placental location (OR 0.84, 95\% CI 0.60-1.20) [13].

New data derived from umbilical cord insertion. A more frequent central umbilical cord insertion (45.2\%) in the RP group, rather than the paracentral (21.5\%), velamentosa $(9.6 \%)$ and marginal $(15.6 \%)$ insertions was observed $(p=0.0001)$ [16].

Notably, it was found that a lower Apgar score at 1 $\min (p=0.0001)$ and at $5 \mathrm{~min}(p=0.02)$ were strongly related with RP [16].

As a novelty, a previous estroprogestin therapy resulted to be a protective factor for retained placenta (OR 0.58 ; 95\% CI 0.31-1.09, $p=0.09$ ) [16].

\section{Discussion}

\section{Main findings}

Retained placenta risk factors which have been assessed are advanced maternal age, previous RP, previous surgical uterine procedures and labor induction with oxytocin. Previous estro-progestins therapy, morphological placental features, endometriosis, ART, Apgar score are new proposal risk factors awaiting further confirmation. Table 2 shows the detailed analysis between every risk factor and the included studies.

\section{Strengths and limitations}

The studies focused on RP risk factors are few and significantly differ in methodology design, inclusion and exclusion criteria and quality. Moreover, heterogeneity of RP definitions makes difficult to build an adequate dataset to meta-analyze.

This consideration supports the certainty that not similar definitions of RP are given in different settings [36]. Timing differences between countries were clearly shown in a European survey, comparing policies about manual removal of placenta at vaginal delivery: in the absence of bleeding the interval until manual removal of placenta varies from less than 30 min to more than $60 \mathrm{~min}$ [43].

Recently, the increased application of an active management of third stage of labor has brought to a significant shortening of the median duration of third stage of labor [43]. Shinar believed that a $30 \mathrm{~min}$ cut off is reasonable because he found $3 \%$ of deliveries with complication when third stage lengthened beyond $30 \mathrm{~min}$ [24].

Some studies do not report the percentage of retained placenta after a well-defined time period but manual removal rates $[2,8,15,31,37]$.

The most widely shared definition of RP is the condition where the placenta is retained after $30 \mathrm{~min}$ of active management of third stage of labor or $60 \mathrm{~min}$ of physiological management [44].

\section{Interpretation}

Although RP is a potentially life-threatening event, it is most likely under-reported. In developed countries it is more common (about 3\% of all vaginal deliveries), but correlated with a lower mortality rate than in less developed ones $(0.1 \%$ of deliveries with $10 \%$ of fatality rate) [1]. The reason of this trend seems to be the higher frequency of uterine surgeries, medicalization of labor and ART pregnancies in more developed countries [21,30].

The great part of studies confirmed a well-established RP association between socio-demographic factors. The relation of an advanced maternal age and a higher number of pregnancies with RP could be explained by the substitution of myometrial fibers replaced by fibrous tissue, predisposing to uterine atony [37]. Women with increased BMI could be disposed to an increased oxidative stress, but whether this phenomenon could lead to changes in placental physiology is still unknown.

The association between placental retention and prior uterine surgery can be explained by the injuries of the endometrial-myometrial junction and the consequent 


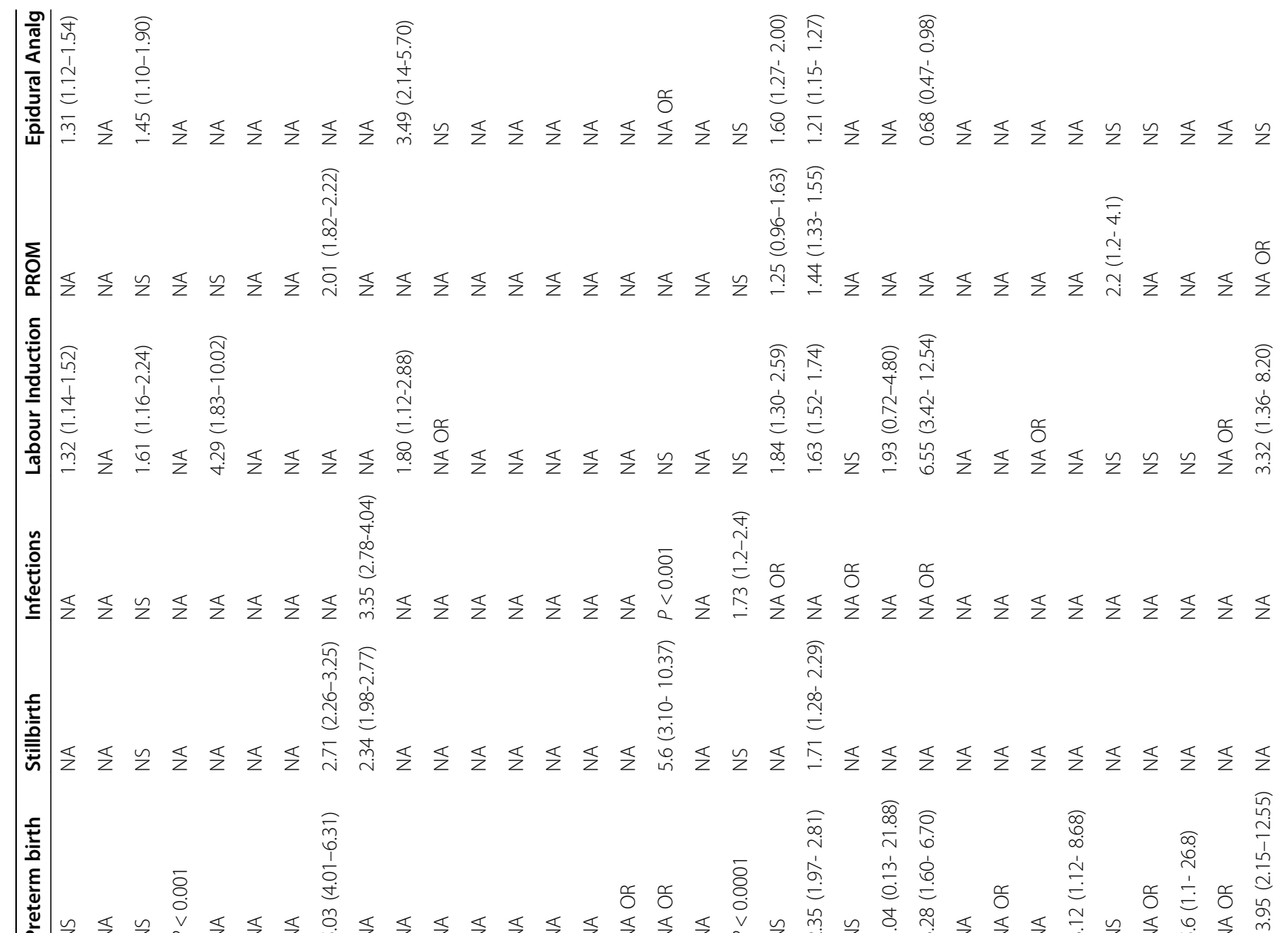

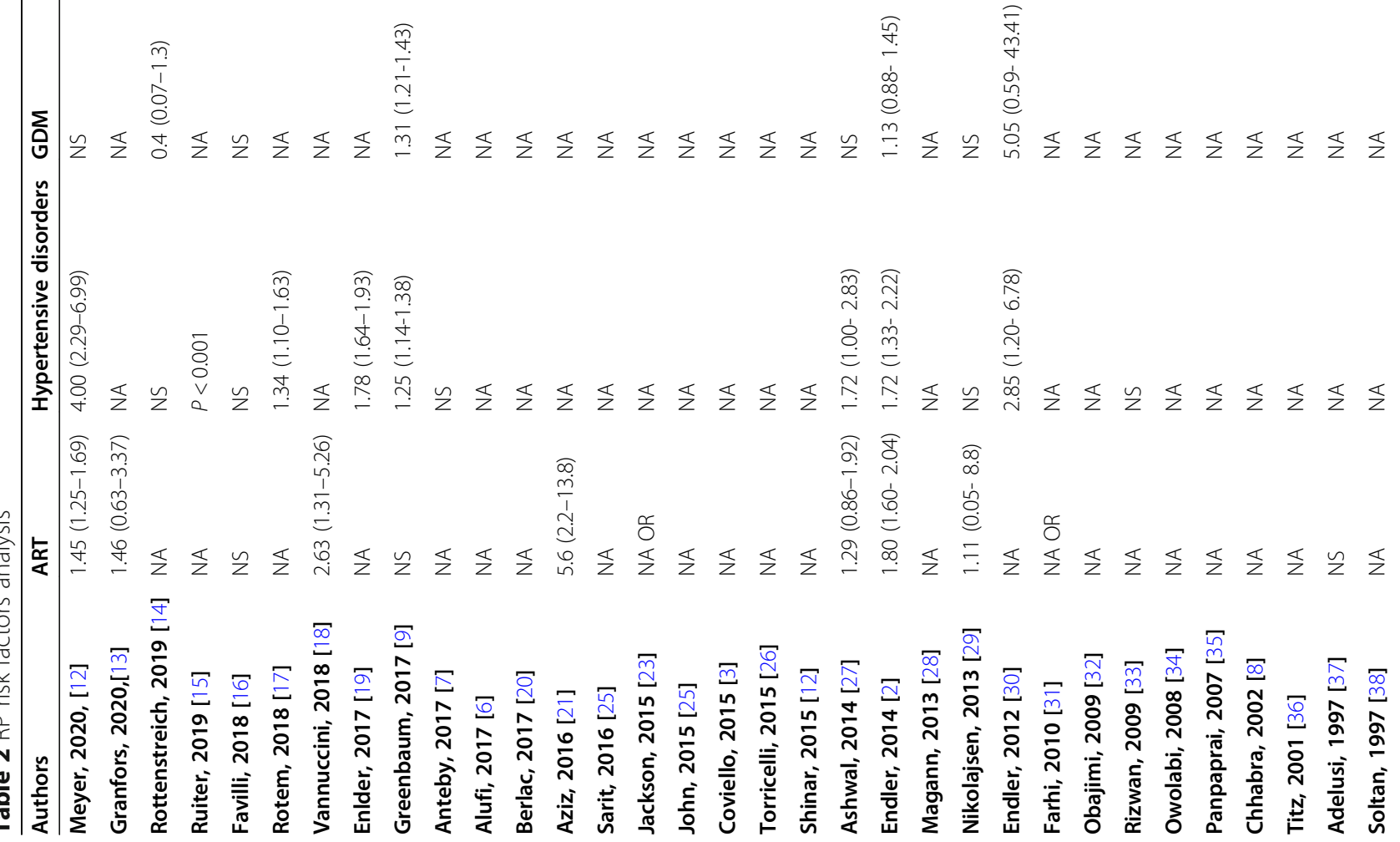




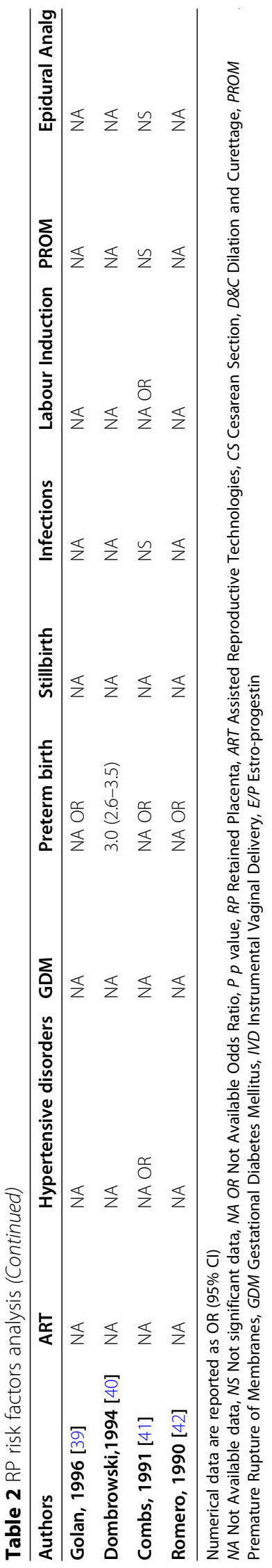




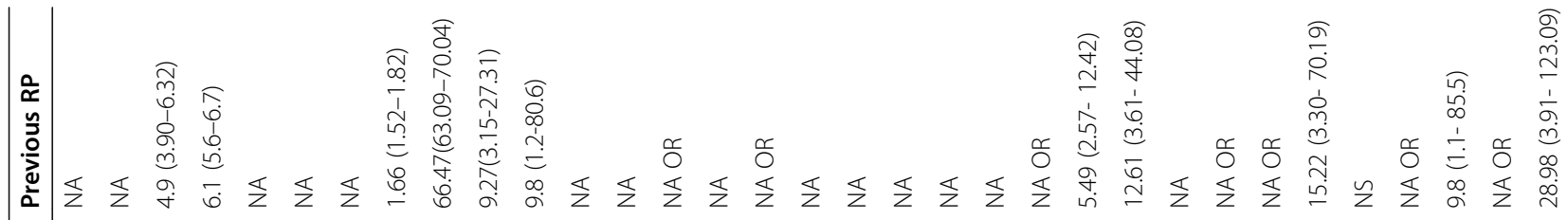

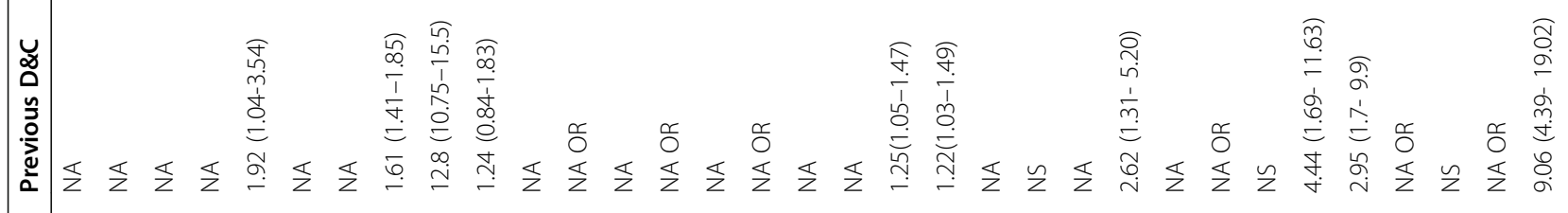

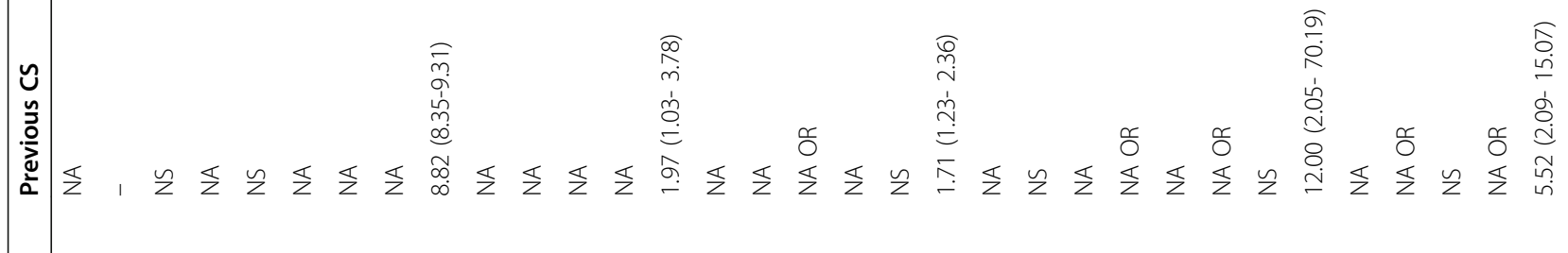

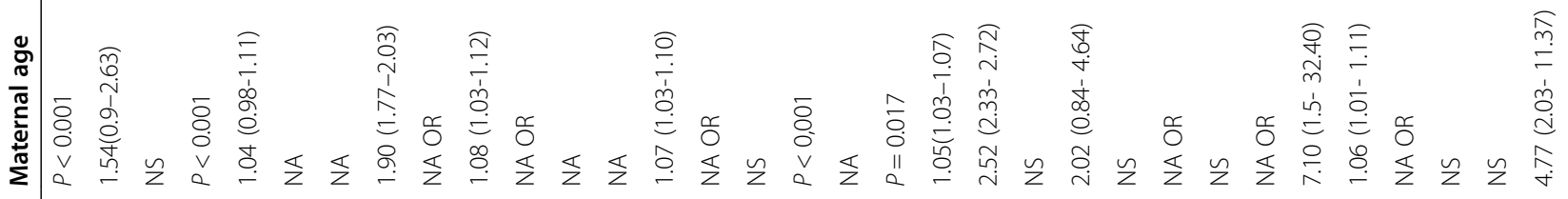

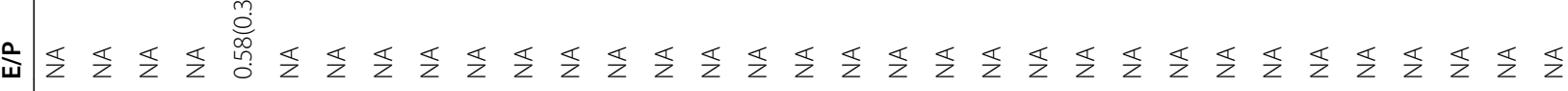

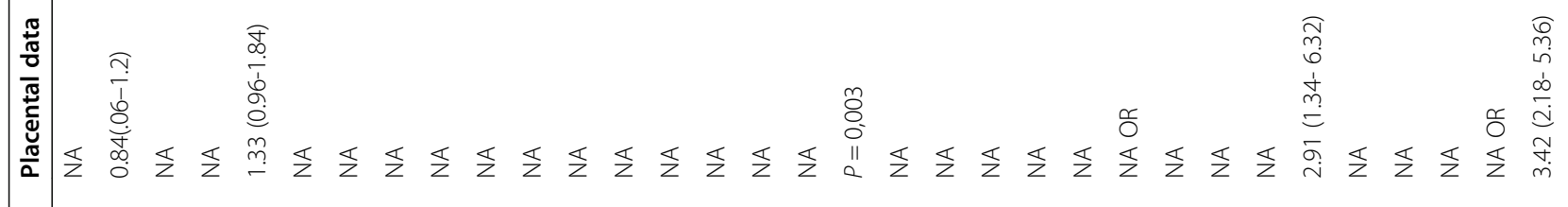




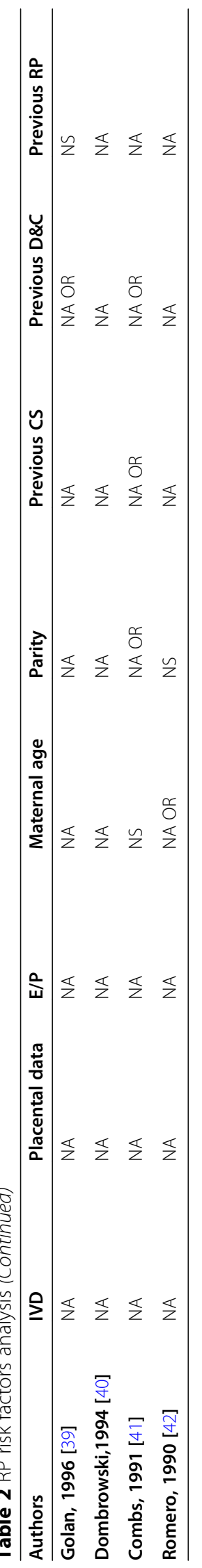


nomalous implantation [34, 37, 38]. Instrumental procedures in non-pregnant uteri were associated with high risk of histologic evidence of abnormal placental implantation and invasiveness in subsequent pregnancies. These cases were three times more prevalent in placenta samples of women with RP than in those with normal placental expulsion (12.3\% vs. $4.3 \%$ ) [9]. Another theory, especially referred to previous CS, is a contractile failure in the retroplacental area as a result of uterine scar [34, 37].

Endometriosis has been found as a RP risk factor: functional and structural abnormalities in the inner myometrium have been demonstrated in Magnetic Resonance Imaging scans and in biopsy. This may lead to defective transformation of spiral arteries and abnormal placentation. Moreover, gynecological surgery for endometriosis seemed to add a further increased risk [20].

In case of uterine fibroids, the uterine cavity distortion or the anomalous placental adhesion at the level of the fibrous septum could explain a pathological placental detachment in the third stage of labor [33,39].

Labor and delivery management are involved in other possible biological pathways of RP. Epidural analgesia, oxitocyn use, instrumental delivery can be related with uterine inadequate contractility $[22,30]$. Oxytocin decreases glutathione and its prolonged use may lead to oxidative stress, predisposing a more vulnerable placenta to retention [30]. Epidural analgesia, seems to depress myometrial contraction, acting on the autonomic nervous system $[22,27,38]$.

The association between operative delivery and RP, could be explained by the prolongation of the second stage of labor, caused in turn by a myometrial fatigue, but also by the occurrence of a dystocia complicating labor $[16,27]$.

Retained placenta may be more frequent in ART pregnancies because of the high estradiol level at the time of embryo-transfer. These patients were characterized by a high rate $(20.8 \%)$ of pregnancy complications related to abnormal placentation [31]. The observed higher rate of placental defects could be also explained with advanced maternal age, ART itself and/or antigenic dissimilarity among oocyte donor and recipient [23].

The same abnormal placentation is usually considered in the Great Obstetrical Syndromes: imbalanced placental perfusion, oxidative stress and apoptosis in placental tissue $[1,2]$, and chronic inflammation status should be considered in hypertensive disorders and in GDM. Preterm birth and IUGR could be closely related to RP through an intrauterine inflammation in the placental site [42]. Besides to the vascular mechanisms described above, animal studies suggest a complex etiology linked to abnormal placental maturation, oxidative stress, imbalanced prostaglandin E2/F2 alpha ratio and decreased steroid hormone receptor status [2]. Indeed, there is an higher frequency of lower placental weight in case of RP, that could be explained by the presence of infarcts or fibrinoid degeneration of decidual arterioles [34, 37, 38]. This may derive as a result of the pathophysiologic origin of RP, thus as a defective placentation determining a regional incomplete vascular remodelling, excessive oxidative stress and emphasis of apoptotic process.

The relation between estroprogestin therapy and RP may be due to a positive effect on basal membrane induced by a stable concentration of hormones on the endometrium and myometrium contractility, or a reduction of incidence of uterine curettage, thanks to a reduced risk of unwanted pregnancy. Concerning the Apgar score, it was speculated that this evidence could be related to a fetal distress, determined by a second stage prolongation or by an abnormal placental implantation site [16]. This last hypothesis was in agreement with previous reports stating a condition of IUGR and/or lower mean birth-weight related to RP [3]. This data should be interpreted with caution because they could be potentially influenced by the gestational period at the delivery.

The characteristics of the "modern obstetric population" (advanced maternal age, nulliparity, higher medicalization of labor, ART pregnancies, endometriosis history) are interesting fields of investigation to try to fill the gaps on RP etiopathogenesis. In light of recent studies on endometriosis, ART procedures and use of estrogen-progestins therapy $[16,20,23]$, we can hypothesize a relevant role of hormonal influence in the RP pathophysiology. Future investigations, particularly in the biomolecular area, would be useful to better understand, confirm or not the few available data.

\section{Conclusions}

This review should remind and aware clinicians on the relevant RP risk factors, in order to improve preventive measures, management and reduce maternal morbidity and mortality. "Old and new data" are not enough robust to draw firm conclusions. Further studies are needed to provide more data on this issue so conduction of a meta-analysis would be possible.

\section{Abbreviations}

RP: Retained Placenta; PPH: Post-partum hemorrhage; PRISMA: Preferred Reporting Items for Systematic Reviews and Meta-Analyses;

EQUATOR: Enhancing the QUAlity and Transparency Of Health Research; BMI: Body Mass Index; CS: Cesarean section; D\&C: Dilation and curettage; ART: (Assisted Reproductive Technologies; (GOS): Great Obstetrical Syndromes; GDM: Gestation Diabetes Mellitus; IUGR: Intra-Uterine Growth Restriction

\section{Supplementary Information}

The online version contains supplementary material available at https://doi. org/10.1186/s12884-021-03721-9.

Additional file 1: Figure 1. Flow diagram of studies identified in the systematic review. 


\section{Acknowledgements}

Not applicable.

\section{Authors' contributions}

M.C and V:T, independently, screened titles and/or abstracts of retrieved articles to identify studies that potentially met the inclusion criteria; consequently, they removed duplicates and examined the remaining references. Moreover, they wrote up the work. A. F, F. P. M. F and S.G. independently, assessed for eligibility the full texts of this studies, checked the drafting of the text and its adequacy. V.B. performed meta-analysis. The author(s) read and approved the final manuscript.

\section{Funding}

No financial support was received for this study.

\section{Availability of data and materials}

All data generated or analyzed during this study are included in this published article and its supplementary information files.

\section{Declarations}

Ethics approval and consent to participate

Not applicable.

\section{Consent for publication \\ Not applicable.}

\section{Competing interests}

The authors declare that they have no competing interests.

\section{Author details}

'Department of Obstetrics and Gynecology, AOUI Verona, University of Verona, Piazzale A. Stefani 1, 37126 Verona, Italy. ${ }^{2}$ Department of Medicine and Surgery, Obstetrics and Gynecology, Centre of Perinatal and Reproductive Medicine, Santa Maria della Misericordia Hospital, University of Perugia, 06156 Perugia, Italy. ${ }^{3}$ Department of Clinic and Community Science, Mangiagalli Hospital, University of Milan, 20122 Milan, Italy. ${ }^{4}$ Department of Medicine and Surgery, Santa Maria della Misericordia Hospital, University of Perugia, 06156 Perugia, Italy.

\section{Received: 2 December 2020 Accepted: 16 March 2021}

\section{Published online: 31 March 2021}

\section{References}

1. Cheung WM, Hawkes A, Ibish S, Weeks AD. The retained placenta: historical and geographical rate variations. J Obstet Gynecol. 2011;31(1):37-42. https:// doi.org/10.3109/01443615.2010.531301.

2. Endler M, Saltvedt S, Cnattingius S, Stephansson O, Wikström AK. Retained placenta is associated with pre-eclampsia, stillbirth, giving birth to a smallfor-gestational-age infant, and spontaneous preterm birth: a national register-based study. BJOG. 2014;121(12):1462-70. https://doi.org/10.1111/14 71-0528.12752.

3. Coviello EM, Grantz KL, Huang CC, Kelly TE, Landy HJ. Risk factors for retained placenta. Am J Obstet Gynecol. 2015;213(6):864. https://doi.org/10.1 016/j.ajog.2015.07.039.

4. Grillo-Ardila CF, Ruiz Parra Al, Gaitán HG, Rodriguez-Malagon N. Prostaglandins for management of retained placenta. Cochrane Database Syst Rev. 2014;16(5):CD010312. https://doi.org/10.1002/14651858.CD010312.

5. Weeks AD. The retained placenta. Best Pract Res Clin Obstet Gynaecol. 2008; 22(6):1103-17. https://doi.org/10.1016/j.bpobgyn.2008.07.005.

6. Alufi A, Mizrachi Y, Lurie S. Reoccurrence of retained placenta at a subsequent delivery: an observational study. J Matern Fetal Neonatal Med. 2017;30(9):1006-9. https://doi.org/10.1080/14767058.2016.1197902

7. Anteby M, Many A, Ashwal E, Yogev Y, Shinar S. Risk factors and complications of manual placental removal after vaginal delivery - how common are additional invasive procedures? J Matern Fetal Neonatal Med. 2017;32(3):384-8. https://doi.org/10.1080/14767058.2017.1379071.

8. Chhabra S, Dhorey M. Retained placenta continues to be fatal but frequency can be reduced. J Obstet Gynecol. 2002;22(6):630-3. https://doi. org/10.1080/0144361021000020402.
9. Greenbaum S, Wainstock T, Dukler D, Leron E, Erez O. Underlying mechanisms of retained placenta: evidence from a population based cohort study. Eur J Obstet Gynecol Reprod Biol. 2017;216:12-7. https://doi.org/10.1 016/j.ejogrb.2017.06.035

10. Perlman NC, Carusi DA. Retained placenta after vaginal delivery: risk factors and management. Int J Women's Health. 2019;7(11):527-34. https://doi. org/10.2147/IJWH.S218933.

11. Zorzela L, Loke YK, loannidis JP, et al. PRISMA harms checklist: improving harms reporting in systematic reviews. BMJ. 2016;352. https://doi.org/10.113 6/bmj.i157.

12. Meyer R, Rottenstreich A, Tsur A, Cahan T, Levin G. Risk factors for third stage placental complications among primigravid women. Placenta. 2020; 99:16-20. https://doi.org/10.1016/j.placenta.2020.07.019.

13. Granfors M, Sandström A, Stephansson O, Belachew J, Axelsson O, Wikström A-K. Placental location and risk of retained placenta in women with a previous cesarean section: a population-based cohort study. Acta Obstet Gynecol Scand. 2020;99(12):1666-73. https://doi.org/10.1111/aogs.

14. Rottenstreich M, Rotem R, Bergman M, Rottenstreich A, GrisaruGranovsky S. Recurrence of retained placenta in multiple consecutive deliveries. J Matern Fetal Neonatal Med. 2019;12:1-6. https://doi.org/10.1 080/14767058.2019.1688294.

15. Ruiter L, Kazemier BM, Mol BWJ, Pajkrt E. Incidence and recurrence rate of postpartum hemorrhage and manual removal of the placenta: a longitudinal linked national cohort study in the Netherlands. Eur J Obstet Gynecol Reprod. 2019;238:114-9. https://doi.org/10.1016/j.ejogrb.2019.05.022.

16. Favilli A, Tosto V, Ceccobelli M, Bini V, Gerli S. Risk factors analysis and a scoring system proposal for the prediction of retained placenta after vaginal delivery. Eur J Obstet Gynecol Reprod Biol. 2018;228:180-5. https://doi.org/1 0.1016/j.ejogrb.2018.06.033

17. Rotem R, Pariente G, Golevski M, Baumfeld Y, Yohay D, Weintraub AY. Association between hypertensive disorders of pregnancy and third stage of labor placental complications. Pregnancy Hypertens. 2018;13:166-70. https://doi.org/10.1016/j.preghy.2018.06.004

18. Vannuccini S, Ferrata C, Perelli F, Pinzauti S, Severi FM, Reis FM, et al. Peripartum and postpartum outcomes in uncomplicated term pregnancy following ART: a retrospective cohort study from two Italian obstetric units. Hum Reproduct Open. 2018;3:1-7. https://doi.org/10.1093/hropen/hoy012.

19. Endler $M$, Cnattingius $S$, Granfors $M$, Wikström AK. The inherited risk of retained placenta: a population based cohort study. BJOG. 2017;125(6):73744. https://doi.org/10.1111/1471-0528.14828.

20. Berlac JF, Hartwell D, Skovlund CW, Langhoff-Roos J, Lidegaard $\varnothing$ Endometriosis increases the risk of obstetrical and neonatal complications. Acta Obstet Gynecol Scand. 2017;96(6):751-60. https://doi.org/10.1111/a ogs.13111.

21. Aziz MM, Guirguis G, Maratto S, Benito C, Forman EJ. Is there an association between assisted reproductive technologies and time and complications of the third stage of labor? Arch Gynecol Obstet. 2016;293(6):1193-6. https:// doi.org/10.1007/s00404-015-3943-3.

22. Sarit A, Sokolov A, Many A. Is epidural analgesia during labor related to retained placenta? J Perinat Med. 2016;44(4):415-9. https://doi.org/10.1515/ jpm-2014-0359.

23. Jackson S, Hong C, Wang ET, Alexander C, Gregory KD, Pisarska MD Pregnancy outcomes in very advanced maternal age pregnancies: the impact of assisted reproductive technology. Fertil Steril. 2015;103(1):76-80. https://doi.org/10.1016/j.fertnstert.2014.09.037.

24. Shinar S, Shenhav M, Maslovitz S, Many A. Distribution of third-stage length and risk factors for its prolongation. AM J Peronatol. 2015:33(10):1023-8. https://doi.org/10.1055/s-0036-1572426.

25. John CO, Orazulike N, Alegbeleye J. An appraisal of retained placenta at the University of Port Harcourt teaching hospital: a five-year review. Niger J Med. 2015;24(2):99-102 https://pubmed.ncbi.nlm.nih.gov/26353418/.

26. Torricelli M, Vannuccini S, Moncini I, et al. Anterior placental location influences onset and progress of labor and postpartum outcome. Placenta. 2015;36(4):463-6. https://doi.org/10.1016/j.placenta.2014.12.018.

27. Ashwal E, Melamed N, Hiersch L, Wiznitzer A, Yogev Y, Peled Y. The incidence and risk factors for retained placenta after vaginal delivery - a single center experience. J Matern Fetal Neonatal Med. 2014;27(18):1897900. https://doi.org/10.3109/14767058.2014.883374.

28. Magann EF, Lutgendorf MA, Keiser SD, et al. Risk factors for prolonged third stage of labor and postpartum hemorrhage. South Med J. 2013;106(2):131-5. https://doi.org/10.1097/SMJ.0b013e3182824d1e. 
29. Nikolajsen S, Lokkegaard EC, Bergholt T. Reoccurrence of retained placenta at vaginal delivery: an observational study. Acta Obstet Gynecol Scand. 2013;92(4):421-5. https://doi.org/10.1111/j.1600-0412.2012.01520.x.

30. Endler M, Grunewald C, Salvedt S. Epidemiology of retained placenta: oxytocin as an independent risk factor. Obstet Gyncol. 2012;1 19(4):801-9. https://doi.org/10.1097/AOG.0b013e31824acb3b.

31. Farhi J, Ben-Haroush A, Andrawus N, et al. High serum oestradiol concentrations in IVF cycles increase the risk of pregnancy complications related to abnormal placentation. Reprod BioMed Online. 2010;21(3):331-7. https://doi.org/10.1016/j.rbmo.2010.04.022.

32. Obajimi GO, Roberts AO, Aimakhu CO, Bello FA, Olayemi O. An appraisal of retained placentae in Ibadan : a five year review. Ann Ib Postgrad Med. 2009;7(1):21-5. https://doi.org/10.4314/aipm.v7i1.64058.

33. Rizwan N, Abbasi RM, Jatoi N. Retained placenta still a continuing cause of maternal morbidity and mortality. J Pak Med Assoc. 2009;59(12):812-4 https://pubmed.ncbi.nlm.nih.gov/20201169/.

34. Owolabi AT, Dare FO, Fasubaa OB, Ogunlola IO, Kuti O, Bisiriyu LA. Risk factors for retained placenta in southwestern Nigeria. Singap Med J. 2008; 49(7):532-7 https://pubmed.ncbi.nlm.nih.gov/18695860/.

35. Panpaprai $P$, Boriboonhirunsarn D. Risk factors of retained placenta in Siriraj hospital. J Med Assoc Thail. 2007;90(7):1293-7 https://pubmed.ncbi.nlm.nih. gov/17710967/.

36. Titiz H, Wallace A, Voaklander DC. Manual removal of the placenta--a case control study. Aust N Z J Obstet Gynecol. 2001;41(1):41-4. https://doi.org/1 0.1111/j.1479-828x.2001.tb01292.x.

37. Adelusi B, Soltan MH, Chowdhry N, Kangave D. Risk of retained placenta: multivariate approach. Acta Obstet Gynecol Scand. 1997;76(5):414-8. https:// doi.org/10.3109/00016349709047821.

38. Soltan MH, Khashoggi T. Retained placenta and associated risk factors. J Obstet Gynaecol. 1997;17(3):245-7. https://doi.org/10.1080/0144361 9750113159

39. Golan A, Raziel A, Pansky M, Bukovsky I. Manual removal of the placenta--its role in intrauterine adhesion formation. Int J Fertil Menopausal Stud. 1996; 41(5):450-1 https://pubmed.ncbi.nlm.nih.gov/8934251/.

40. Dombrowski MP, Bottoms SF, Aziz A, Saleh A, Hurd WW, Romero R. Third stage of labor: analysis of duration and clinical practice. Am J Obstet Gynecol. 1995; 172(4 Pt 1):1279-84. https://doi.org/10.1016/0002-9378(95)91493-5.

41. Combs CA, Laros RK Jr. Prolonged third stage of labor: morbidity and risk factors. Obstet Gynecol. 1991;77(6):863-7 https://pubmed.ncbi.nlm.nih.gov/2 030858/.

42. Romero R, Hsu YC, Athanassiadis AP, et al. Preterm delivery: a risk factor for retained placenta. Am J Obstet Gynecol. 1990;163(3):823-5. https://doi.org/1 0.1016/0002-9378(90)91076-0.

43. Deneux-Tharaux C, Macfarlane A, Winter C, et al. Policies for manual removal of placenta at vaginal delivery: variations in timing within Europe. BJOG. 2009;116(1):119-24. https://doi.org/10.1111/j.1471-0528.2008.01996.x.

44. Delgado Nunes V, Gholitabar M, Sims JM, Bewley S. Guideline development group intrapartum care of healthy women and their babies: summary of updated NICE guidance. BMJ. 2014;349. https://doi.org/10.1136/bmj.g6886.

\section{Publisher's Note}

Springer Nature remains neutral with regard to jurisdictional claims in published maps and institutional affiliations.

Ready to submit your research? Choose BMC and benefit from:

- fast, convenient online submission

- thorough peer review by experienced researchers in your field

- rapid publication on acceptance

- support for research data, including large and complex data types

- gold Open Access which fosters wider collaboration and increased citations

- maximum visibility for your research: over $100 \mathrm{M}$ website views per year

At BMC, research is always in progress.

Learn more biomedcentral.com/submissions 